\title{
STUDIES ON AMINO ACID EXCRETION IN MAN. IV. PEPTIC ULCER ${ }^{1}$
}

\author{
By JOSEPH B. KIRSNER, A. LEONARD SHEFFNER,2 WALTER L. PALMER, AND \\ KENNETH STERLING ${ }^{3}$
}

\author{
(From the Frank Billings Medical Clinic, Department of Medicine, University of Chicago, \\ Chicago)
}

(Submitted for publication January 3, 1950; accepted, March 13, 1950)

The observation of gastric ulcerations in dogs and rats maintained on low intakes of protein (1) and the current emphasis upon the value of high protein diets in the treatment of peptic ulcer (2) have stimulated interest in the status of protein metabolism in this disease. The present paper deals with a comparative study of certain aspects of amino acid metabolism in three normal persons and in four patients with peptic ulcer. In addition to the conventional nitrogen balances, eight amino acids : leucine, isoleucine, valine, threonine, arginine, histidine, lysine, and methionine, were measured microbiologically in the food, plasma, and in six-day collections of the urine and feces. The plasma proteins were studied electrophoretically in one of the controls and in the four patients.

\section{METHOD OF STUDY}

Subjects. Three healthy young men, three patients with chronic gastric ulcer, and one with chronic duodenal ulcer were studied in the metabolism unit of the Albert Merritt Billings Hospital. Two of the controls in these subjects (J.D. and R.G.H.) have been described previously (3); the body surface areas were 1.84 and 2.12 square meters, respectively. The essential data in control R.S.L. are as follows: height $185 \mathrm{~cm}$., initial weight $81.5 \mathrm{~kg}$., surface area 2.12 square meters, basal metabolic rate -17 , basal calories 1,780 . In addition to the physical examination and usual laboratory procedures, normal results were obtained for various tests of renal and hepatic function, oral glucose tolerance, serum electrolytes; plasma proteins, and gastric secretion.

The pertinent data in the four patients are as follows: W.G., male, 58 years of age, had experienced ulcer distress for 26 years. Numerous roentgen studies demonstrated a persistent ulcer crater on the lesser curvature of the stomach at the level of the angulus. The lesion

1 This study was supported in part by grants from the Evaporated Milk Association and the American Dairy Association.

2 Present address : Department of Biological Chemistry, University of Illinois, College of Medicine, Chicago, Ill.

8 Present address: Department of Medicine, Harvard Medical School, Boston, Mass. was visualized in 104 of 117 gastroscopic examinations performed during a period of 12 years.

The patient was slightly underweight; the blood pressure was moderately elevated. The blood counts, urine analyses, serum electrolytes, glucose tolerance, and hepatic function were normal. The blood urea nitrogen was increased slightly and the urea clearance measured 50 per cent of normal. The maximum free hydrochloric acid (histamine stimulation) was 12 clinical units; earlier tests had disclosed higher levels. The total plasma proteins (seven determinations) ranged between 6.69 and $7.44 \mathrm{gm}$. per cent, albumin between 4.38 and 5.06 , and globulin between 2.20 and $2.43 \mathrm{gm}$. per cent. Height was $159 \mathrm{~cm}$., initial weight $52.9 \mathrm{~kg}$., surface area 1.52 square meters, basal metabolic rate -7 , and basal calories 1,220. Magnesium carbonate, $2.0 \mathrm{gm}$., was prescribed daily.

J.D., male, 50 years of age, had noted ulcer symptoms for 27 years. Numerous X-rays disclosed a persistent ulcer crater on the lesser curvature of the stomach at the level of the angulus. Rheumatic heart disease with mitral stenosis and insufficiency had been present since the age of 13 and had been complicated by auricular fibrillation and cardiac insufficiency. The patient was not in cardiac failure at the time of the study. He was moderately underweight; the edge of the liver was palpable $9 \mathrm{~cm}$. below the costal margin. The thymol turbidity measured 9.4 units; the total serum cholesterol was increased moderately but the cholesterol-cholesterol ester ratio was normal. Other tests of hepatic function were normal, as were the blood counts, urine, renal function, serum electrolytes, and oral glucose tolerance. The maximum free hydrochloric acid (histamine stimulation) was 16 clinical units; earlier tests had disclosed higher levels of acidity. The total plasma proteins (six determinations) ranged between 7.02 and $7.78 \mathrm{gm}$. per cent. Height was $165 \mathrm{~cm}$., initial weight $45.4 \mathrm{~kg}$, , body surface area 1.46 square meters, basal metabolic rate -8 , and basal calories 1,190 . The only medication consisted of digilanid, $0.00033 \mathrm{gm}$. daily.

G.D., male, 45 years of age, had experienced recurrent ulcer distress for 12 years. Numerous roentgen and gastroscopic examinations demonstrated an ulcer crater on the lesser curvature of the stomach above the angulus. The physical examination and the laboratory procedures cited above were normal. The maximum free hydrochloric acid (histamine stimulation) was 70 clinical units. The total plasma proteins (four measurements) ranged between 6.36 and $7.04 \mathrm{gm}$. per cent, albumin between 4.45 and 4.80 , and globulin between 1.90 and 2.76 
gm. per cent. Height was $178 \mathrm{~cm}$., initial weight $65.5 \mathrm{~kg}$., body surface area 1.83 square meters, basal metabolic rate +9 , and basal calories 1,750 . Two $\mathrm{gm}$. each of magnesium and calcium carbonate and $0.09 \mathrm{gm}$. of $\mathrm{sec}$ onal were taken daily.

J.DeJ., male, 58 years of age, had experienced recurrent ulcer symptoms for six years. Roentgen examination disclosed an ulcer crater in the duodenal bulb. The various laboratory procedures were normal. The maximum free hydrochloric acid (histamine stimulation) was 111 clinical units. The total plasma proteins ranged between 6.58 and $6.90 \mathrm{gm}$. per cent, albumin between 3.91 and 4.92, and globulin between 1.66 and $2.99 \mathrm{gm}$. per cent. Height was $157 \mathrm{~cm}$., initial weight $66.2 \mathrm{~kg}$., body surface area 1.65 square meters, basal metabolic rate +13 , and basal calories 1,620. Seconal, $0.09 \mathrm{gm}$., was prescribed nightly; the patient also received a total of $0.6 \mathrm{gm}$. of cascara sagrada.

An active ulcer was demonstrated in each of the four patients. There had been no operations recently. There was no vomiting. The feces did not contain occult blood by the benzidine test. The body temperature remained normal. The plasma volumes, measured at the onset of the metabolic period, were for controls : J.D., 2,610 cc., and R.G.H., 2,728 cc.; and for patients: W.G., 2,538 cc.; J.D., 2,644 cc., and G.D., 3,397 cc.

\section{DIET}

Fluids were allowed ad libitum; the intake of fluid and the urinary output were measured daily. All subjects received a weighed, three-meal bland diet, including proteins of high biologic value such as beef, eggs, and milk. One $\mathrm{gm}$. of protein was given per kilogram of body weight per day. The daily intake of nitrogen approximated minimum requirements for normal maintenance (4). The values were for the controls: J.D., $7.20 \mathrm{gm}$; R.G.H., $7.20 \mathrm{gm}$.; and R.S.I., $6.75 \mathrm{gm}$; ; and for the patients: W.G., 5.98 gm.; J.D., 5.33 gm.; G.D., 6.16 gm.; and J.DeJ., $6.88 \mathrm{gm}$. per square meter of body surface area. The caloric intake was calculated to include the requirements for basal energy and for ordinary activity; it averaged 3,200 for each of the controls, and for the patients W.G., 2,470, J.D., 2,457, G.D., 2,554, and J.DeJ., 2,432 daily. The diet contained sufficient amounts of vitamins and minerals. Two or three $\mathrm{gm}$. of table salt were added to the food daily except in patient J.D. whose intake was limited to $1.0 \mathrm{gm}$. Each metabolic period was of six days' duration; the test diet was administered to controls J.D. and R.G.H. and patient J.DeJ. for 10 days, and to control R.S.L. and patients W.G., J.D., and G.D. for approximately six days prior to the actual study. Normal activity was permitted; however, the patients were less active than the controls.

The preparation and analysis of the food, plasma, urine, and feces, and the microbiological methods employed for the determination of individual amino acids have been described in preceding papers (5). The measurements in food, urine and feces were for the total quantity of each amino acid in acid-hydrolyzed samples. In plasma, the free amino acids were measured in tungstic acid filtrates prepared according to Hier and Bergeim (6). Total non-protein amino acids 4 were determined on acidhydrolyzed tungstic acid filtrates. Total nitrogen was determined by a semi-micro Kjeldahl procedure (7), urea by the urease method, and free ammonia nitrogen by distillation into boric acid after alkalinization of the sample with potassium carbonate. Nitrogen loss in the sweat was not taken into account.

\section{RESULTS}

The body weights in all subjects did not vary significantly. The values for total plasma proteins, albumin, and globulin were unchanged. The

TABLE I

Nitrogen balances and outputs of urinary and fecal nitrogen during administration of a standardized bland diet

\begin{tabular}{|c|c|c|c|c|c|}
\hline & \multirow{2}{*}{ N Intake } & \multicolumn{3}{|c|}{ Output of } & \multirow{2}{*}{ N Balance } \\
\hline & & Urea & $\begin{array}{c}\text { Total } \\
\text { urine } \mathrm{N}\end{array}$ & Fecal N & \\
\hline \multirow[b]{2}{*}{$\begin{array}{c}\text { Controls: } \\
\text { J.D. } \\
\text { R.G.H. } \\
\text { R.S.L. }\end{array}$} & $\underset{d a y}{g m . / m^{2} /}$ & $\underset{d a y}{g m . / m^{2} /}$ & $\underset{d a y}{g m . / m^{2} /}$ & $\underset{d a y}{g m_{0} / \mathrm{m}^{2} /}$ & $\underset{d a y}{g m . / m^{2} /}$ \\
\hline & $\begin{array}{l}7.20 \\
7.20 \\
6.75\end{array}$ & $\begin{array}{l}4.66 \\
4.91 \\
4.38\end{array}$ & $\begin{array}{l}6.15 \\
6.29 \\
5.57\end{array}$ & $\begin{array}{l}0.48 \\
0.56 \\
0.53\end{array}$ & $\begin{array}{l}+0.57 \\
+0.35 \\
+0.65\end{array}$ \\
\hline $\begin{array}{l}\text { Patients: } \\
\text { W.G. } \\
\text { J.D. } \\
\text { G.D. } \\
\text { J. DeJ. }\end{array}$ & $\begin{array}{l}5.98 \\
5.33 \\
6.16 \\
6.88\end{array}$ & $\begin{array}{l}4.30 \\
4.10 \\
4.43 \\
5.28\end{array}$ & $\begin{array}{l}4.83 \\
4.82 \\
5.58 \\
6.54\end{array}$ & $\begin{array}{l}0.56 \\
0.44 \\
0.46 \\
0.63\end{array}$ & $\begin{array}{r}+0.59 \\
+0.07 \\
+0.12 \\
-0.29\end{array}$ \\
\hline
\end{tabular}

nitrogen balances were slightly positive except in patient J.DeJ. in whom the balance was slightly negative (Table I). The outputs of urea nitrogen were similar in the two groups. The daily excretion of ammonia nitrogen did not vary significantly.

The data for amino acids are summarized in Tables II and III. Inasmuch as the daily intakes of the individual amino acids per square meter of body surface area were very similar for the controls and the patients, the values are averaged for the entire series. The individual amino acid outputs in the urine and feces and the amino acid concentrations in plasma are averaged separately for each group.

4 Evidence obtained recently by Sheffner and Bergeim indicates that tungstic acid filtrates when dialyzed for a sufficient length of time do not contain protein as determined by microbiological assay of individual amino acids. 
TABLE II

Total excretion of eight amino acids in urine and feces of three normal individuals and four patients with peptic ulcer

\begin{tabular}{|c|c|c|c|c|c|c|c|c|c|}
\hline & \multirow{3}{*}{$\begin{array}{c}\text { Amino } \\
\text { acids } \\
\text { ingested }\end{array}$} & \multicolumn{4}{|c|}{ Amino acids in urine } & \multicolumn{4}{|c|}{ Amino acids in feces } \\
\hline & & \multicolumn{2}{|c|}{ Normal } & \multicolumn{2}{|c|}{ Peptic ulcer } & \multicolumn{2}{|c|}{ Normal } & \multicolumn{2}{|c|}{ Peptic ulcer } \\
\hline & & Average & Range & Average & Range & Average & Range & Average & Range \\
\hline $\begin{array}{l}\text { Leucine } \\
\text { Isoleucine } \\
\text { Valine } \\
\text { Threonine } \\
\text { Arginine } \\
\text { Histidine } \\
\text { Lysine } \\
\text { Methionine }\end{array}$ & \begin{tabular}{|c|}
$m g . / m^{2} / d a y$ \\
3,150 \\
2,130 \\
2,200 \\
1,530 \\
2,000 \\
1,050 \\
2,600 \\
900
\end{tabular} & \begin{tabular}{|c|} 
mg./m2/day \\
12 \\
7 \\
10 \\
32 \\
12 \\
117 \\
50 \\
5
\end{tabular} & \begin{tabular}{|c|}
$m g . / m^{2} / d a y$ \\
$6-13$ \\
$3-8$ \\
$8-13$ \\
$28-38$ \\
$6-15$ \\
$72-187$ \\
$33-75$ \\
$2-7$
\end{tabular} & $\begin{array}{c}m g . / m^{2} / \text { day } \\
13 \\
10 \\
15 \\
25 \\
17 \\
55 \\
45 \\
5\end{array}$ & $\begin{array}{c}m g . / m^{2} / \text { day } \\
8-18 \\
8-15 \\
10-22 \\
18-22 \\
13-22 \\
37-70 \\
30-65 \\
3-7\end{array}$ & \begin{tabular}{|c} 
mg. $/ \boldsymbol{m}^{2} /$ day \\
150 \\
120 \\
150 \\
140 \\
120 \\
64 \\
180 \\
50
\end{tabular} & \begin{tabular}{|c|}
$m g . / m^{2} /$ day \\
$130-170$ \\
$100-130$ \\
$130-170$ \\
$130-150$ \\
$70-150$ \\
$50-70$ \\
$150-220$ \\
$20-70$
\end{tabular} & \begin{tabular}{|c|}
$m g . / m^{2} /$ day \\
180 \\
120 \\
170 \\
120 \\
130 \\
50 \\
200 \\
70
\end{tabular} & \begin{tabular}{|c} 
mg./ $/ m^{2} / d a y$ \\
$150-220$ \\
$100-150$ \\
$130-180$ \\
$80-150$ \\
$100-170$ \\
$30-80$ \\
$170-280$ \\
$50-80$
\end{tabular} \\
\hline
\end{tabular}

For seven of the eight amino acids, the amounts excreted in the urine were very similar in both groups. Smaller outputs of histidine were noted in the ulcer patients, the lowest value being obtained in patient W.G. The total individual amino acid outputs in the feces were almost identical in the normal subjects and the ulcer patients. The values for free isoleucine, valine, histidine, and methionine in plasma were similar in the two groups. The average concentrations of free leucine and threonine were higher in the controls, attributable almost entirely to the increased values in one of this group (R.S.L.). The levels of arginine were consistently elevated in the ulcer patients; higher values for lysine also were noted in two of this group. However, the differences are small and do not appear significant. The results in patient J.D. with hepatomegaly in addition to gastric ulcer did not differ appreciably from those obtained in the other patients.
The average concentrations of total non-protein amino acids in plasma were consistently higher in the ulcer patients; indeed, for four amino acids (leucine, isoleucine, valine, arginine), the minimum values exceeded the maximum figures obtained in the control group. Among the ulcer cases, J.D. tended to approach the normal range most closely; however, in subsequent studies he also exhibited high values.

The four patients were restudied approximately one year later. The total non-protein amino acid levels now were normal in patients G.D. ${ }^{5}$ and J.DeJ.; symptoms had subsided and roentgen examination indicated complete healing of the ulcers. Patients W.G. and J.D. again manifested increased plasma non-protein amino acid values; in these subjects, however, symptoms had persisted and the gastric ulcers were demonstrable roentgenologically.

5 The ulcer recurred in this patient five weeks later.

TABLE III

Concentrations of eight amino acids in plasma of three normal individuals and four patients with peptic ulcer

\begin{tabular}{|c|c|c|c|c|c|c|c|c|}
\hline & \multicolumn{4}{|c|}{ Free amino acids in plasma } & \multicolumn{4}{|c|}{$\begin{array}{l}\text { Total non-protein amino acids in } \\
\text { tungstic acid filtrates of plasma }\end{array}$} \\
\hline & \multicolumn{2}{|c|}{ Normal } & \multicolumn{2}{|c|}{ Peptic ulcer } & \multicolumn{2}{|c|}{ Normal } & \multicolumn{2}{|c|}{ Peptic ulcer } \\
\hline & Average & Range & Average & Range & Average & Range & Average & Range \\
\hline $\begin{array}{l}\text { Leucine } \\
\text { Isoleucine } \\
\text { Valine } \\
\text { Threonine } \\
\text { Arginine } \\
\text { Histidine } \\
\text { Lysine } \\
\text { Methionine }\end{array}$ & $\begin{array}{c}\gamma / c c . \\
29 \\
18 \\
28 \\
27 \\
17 \\
16 \\
26 \\
6\end{array}$ & $\begin{array}{c}\gamma / c c . \\
20-40 \\
17-20 \\
20-39 \\
19-42 \\
15-19 \\
12-21 \\
24-28 \\
5-7\end{array}$ & $\begin{array}{c}\gamma / c c . \\
19 \\
15 \\
32 \\
15 \\
29 \\
14 \\
36 \\
5\end{array}$ & $\begin{array}{c}\gamma / c c . \\
18-21 \\
13-18 \\
26-37 \\
10-19 \\
26-35 \\
12-15 \\
22-47 \\
3-6\end{array}$ & $\begin{array}{c}\gamma / c c . \\
48 \\
32 \\
42 \\
45 \\
33 \\
24 \\
52 \\
6\end{array}$ & $\begin{array}{c}\gamma / c c . \\
43-52 \\
28-37 \\
39-47 \\
37-54 \\
27-44 \\
22-28 \\
39-69 \\
5-7\end{array}$ & $\begin{array}{c}\gamma / c c . \\
80 \\
49 \\
74 \\
63 \\
77 \\
30 \\
88 \\
10\end{array}$ & $\begin{array}{c}\gamma / c c . \\
64-104 \\
44-55 \\
61-100 \\
36-88 \\
50-95 \\
23-38 \\
42-107 \\
5-14\end{array}$ \\
\hline
\end{tabular}


Electrophoretic patterns of the plasma proteins were obtained in the four patients during their re-examination, and in one of the controls (R.S.L.). Fast-moving, apparently abnormal boundaries were present in the patterns of patients G.D., W.G., and J.DeJ.; but not in J.D., nor in the normal subject. Shortly after beginning the electrophoresis, the boundary appeared before the albumin and was clearly visible well in advance of the albumin after the current had been maintained for 30 minutes. It had moved beyond the optical channel of the cell at the time of the final exposures. The final electrophoretic patterns presented very minor deviations from normal, such as slightly elevated alpha-2-globulins in W.G. and J.DeJ. The patterns of patient G.D. after 32 and $681 / 3$ minutes of electrophoresis illustrate the fastmoving boundary, which had a mobility more than twice that of albumin (Figure 1).

\section{COMMENT}

The present data do not demonstrate any specific or gross abnormality in protein metabolism in patients with peptic ulcer. The smaller amounts of histidine in the urine and the minor fluctuations in the free amino acids of plasma do not appear significant. The normal range is wide (6) ; larger variations may become apparent as more normal subjects are studied. A comparative analysis of the utilization of protein administered as meat and eggs, skimmed milk powder, evaporated milk and protein hydrolysate (to be reported later) likewise has indicated normal assimilation of whole protein by patients with gastric ulcer (8). Co Tui and his associates (9) and Kenamore and his associates (10) observed pronounced retentions of nitrogen in patients given large quantities of a protein hydrolysate orally. The positive balances undoubtedly reflect previously inadequate
PLASM OF NORUL CONTROL R.S.I.
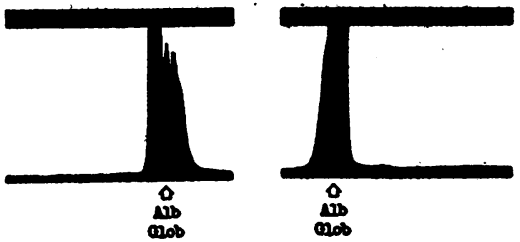

25 min.s

30 sec.

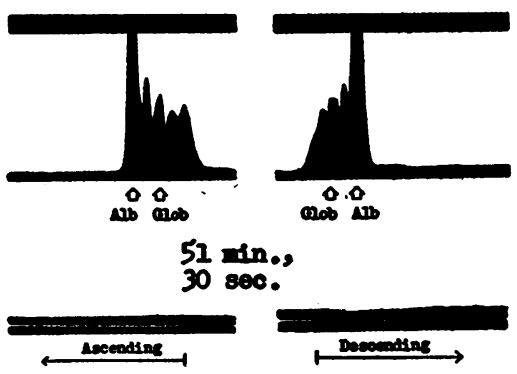

PISSII OF PATIXYIT Q.D.

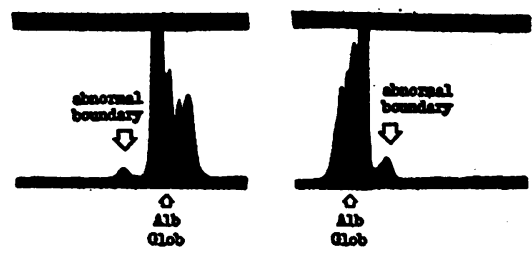

32 min.

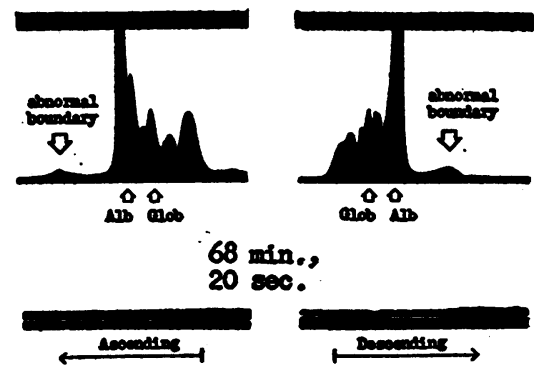

Fig. 1. Electrophoretic Patterns of Plasma Proteins in Patient G.D.

Electrophoresis in sodium diethylbarbiturate (veronal) buffer $(\mathrm{pH} \mathrm{8.6,} \mathrm{ionic} \mathrm{strength} 0.1$ ) at a potential gradient of 5.8 volts $/ \mathrm{cm}$., bath temperature $1.5^{\circ} \mathrm{C}$. Plasma diluted with buffer after dialysis to four times the volume before dialysis.

The fast-moving boundary in the above and in the other plasmas, when it was observed, had an average mobility of $-14.4 \times 10^{-5} \mathrm{~cm} .{ }^{2} / \mathrm{volt} / \mathrm{sec}$. (descending) and $-19.1 \times 10^{-5} \mathrm{~cm} .{ }^{2} / \mathrm{volt} / \mathrm{sec}$. (ascending). The average descending mobility of albumin in the same plasmas was $-7.0 \times 10^{-5}$ $\mathrm{cm} .{ }^{2} /$ volt/sec. 
TABLE IV

Percentage composition* of eight amino acids in food, urine, and feces of three normal individuals and four patients with peptic ulcer

\begin{tabular}{|c|c|c|c|c|c|}
\hline & \multirow{2}{*}{ Food } & \multicolumn{2}{|c|}{ Urine } & \multicolumn{2}{|c|}{ Feces } \\
\hline & & Normal & $\begin{array}{l}\text { Peptic } \\
\text { ulcer }\end{array}$ & Normal & $\begin{array}{c}\text { Peptic } \\
\text { ulcer }\end{array}$ \\
\hline $\begin{array}{l}\text { Leucine } \\
\text { Isoleucine } \\
\text { Valine } \\
\text { Threonine } \\
\text { Arginine } \\
\text { Histidine } \\
\text { Lysine } \\
\text { Methionine }\end{array}$ & $\begin{array}{c}\text { per cent } \\
20 \\
13 \\
14 \\
10 \\
13 \\
7 \\
17 \\
6\end{array}$ & $\begin{array}{c}\text { per cent } \\
5 \\
3 \\
4 \\
13 \\
5 \\
48 \\
20 \\
2\end{array}$ & $\begin{array}{c}\text { per cent } \\
7 \\
5 \\
8 \\
14 \\
9 \\
30 \\
24 \\
3\end{array}$ & $\begin{array}{c}\text { per cent } \\
16 \\
12 \\
15 \\
14 \\
12 \\
7 \\
19 \\
5\end{array}$ & $\begin{array}{c}\text { per cent } \\
17 \\
12 \\
16 \\
12 \\
12 \\
5 \\
19 \\
7\end{array}$ \\
\hline
\end{tabular}

* Per cent of each amino acid contributing to total of the eight amino acids measured.

All values are group averages.

diets; indeed, they demonstrate that the ulcer patient utilizes protein efficiently when given sufficient amounts. Sappington and Bockus (11) investigated the protein requirements of five patients by means of nitrogen balance surveys; each had had a low intake of protein prior to the study. Evidence of previous protein depletion was obtained in two and probably in a third case. It is to be noted that the plasma proteins are normal in uncomplicated peptic ulcer (12); furthermore, gastroduodenal ulcerations have not been observed in individuals severely depleted of protein (13).

The patterns of amino acid excretion in the urine and feces were very similar in the two groups (Table IV). In comparison with the amino acid content of the food, the urine contained smaller percentages of leucine, isoleucine, valine, arginine, and methionine and much larger proportions of histidine. On the other hand, in both the normal subjects and the ulcer patients, the patterns of amino acid excretion in the feces were similar to that of the food.

The increases in individual amino acids in acidhydrolyzed tungstic acid filtrates of plasma from the ulcer group are noteworthy. Marino and Saladino (14) are reported to have demonstrated larger amounts of polypeptides in the blood of patients with peptic ulcer. Godfried (15) noted "hyperpolypeptidemia" soon after hemorrhage. Becher and Herrmann (16) found higher values for "bound" amino nitrogen (total minus free amino acids) in the blood of patients with acute atrophy of the liver, polycythemia, leukemia, and severe renal insufficiency. Increases in polypeptides also have been described in severe diabetes, suppurative processes and ulcerative colitis. Christensen and colleagues (17) concluded that peptidemia was not characteristic of neoplastic and hepatic diseases, venous thrombosis, or severe burns without azotemia ; increased, but not excessive, values were noted in patients with the nephrotic syndrome. It is of interest that in the present study the elevated non-protein amino acid values decreased to normal in two cases, coincident with the healing of the ulcer; however, the precise interpretation of this observation must await further study. Subsequent experiments did not reveal the presence of protein in dialyzed tungstic acid filtrates of plasma in the patients studied.

The significance of the fast-moving component noted in the electrophoretic patterns of the plasma proteins in three of the four patients is not apparent. It was not observed in the one normal subject examined and had not been encountered previously in normal persons or in patients with hepatic disease, neoplasm or infection. It was not seen in subsequent electrophoretic studies ${ }^{6}$ of both heparinized ${ }^{7}$ and citrated plasma from two additional patients with gastric ulcer and one with duodenal ulcer. The rapidly migrating peak does not appear to resemble the abnormal boundaries previously reported in the literature, including the "X component" of Seibert (18) ; abnormal proteins in the blood of cancer patients (19) ; the fastmoving peak noted in normal plasma (20) and later shown by Svensson (21) to be a "false boundary ;" and the heparin-albumin complex ("C component") of Chargaff and his coworkers (22), observed in patterns containing a heparin peak as well. Berg and associates (23) have noted in the plasmas of patients with bullous dermatological diseases an extremely rapidly moving peak, much faster than and presumably different from the present component. Shedlovsky (24), in unpublished experiments, observed a similar, perhaps

6 Kindly performed by E. Goldwasser, Department of Biochemistry, University of Chicago.

7 The heparin used in all studies was a product of $\mathbf{H y n}$ son, Westcott and Dunning, (Lot No. 200). 
identical, fast-moving boundary in sera from patients with acute rheumatic fever with active involvement of joints, in synovial fluids, and in some blood sera obtained at necropsy from cardiac patients. In recent studies on pooled normal human plasma, Drs. E. J. Cohn and K. Schmid (25) of the Department of Physical Chemistry, Harvard Medical School, have detected and separated, as a minor constituent of a fraction of low molecular weight proteins, a component of mobility quite similar to that of the rapidly moving component here reported. It remains to be determined whether this constituent is present in minute amounts in all plasmas or whether it occurs in abnormal plasmas, sometimes included in plasma pools. Nucleic acid (26), hyaluronic acid (27) and probably many other constituents of the tissues have electrophoretic mobilities greater than albumin. Further investigation of the problem obviously is desirable.

\section{SUM M ARY}

1. Nitrogen balances and microbiological measurements of eight amino acids in the food, plasma, urine, and feces were obtained in three normal men and in four male patients with active peptic ulcer, given a constant diet containing minimally adequate amounts of high-quality protein.

2. There were no demonstrably significant differences between the two groups with respect to nitrogen balance, output of urea nitrogen, excretion of amino acids in the urine and feces, and the free amino acids in plasma.

3. The concentrations of each of the eight amino acids measured in acid-hydrolyzed tungstic acid filtrates of plasma were increased in the ulcer group.

4. A fast-moving component was observed during electrophoresis of the plasma proteins of three patients, in two of whom the ulcer had healed. This component was not demonstrated in the heparinized plasma of one normal subject and one patient with active gastric ulcer, and it was not observed in both citrated and heparinized plasma from three additional patients with peptic ulcer. At the end of electrophoresis the pattern in all cases appeared within the normal range or presented very minor deviations.
Valuable assistance was provided by Miss Blanche Parish, R.N., in the care of the subjects, Miss Minnie Brandt in the preparation and administration of the diet, and by Mr. John Grabow in the laboratory work.

\section{BIBLIOGRAPHY}

1. a. Hoelzel, F., and DaCosta, E., Production of ulcers in the prostomach of rats by protein restriction. Proc. Soc. Exper. Biol. \& Med., 1932, 29, 382.

b. Howes, E. L., and Vivier, P. J., The relation of diet to the occurrence of gastric lesions in the rat. Am. J. Path., 1936, 12, 689.

c. Weech, A. A., and Paige, B. H., Nutritional edema in the dog. IV. Peptic ulcer produced by the same low protein diet that leads to hypoproteinemia and edema. Am. J. Path., 1937, 13, 249.

d. Hoelzel, F., and DaCosta, E., Production of peptic ulcers in rats and mice by diets deficient in proteins. Am. J. Digest. Dis. and Nutrition, 1937, 4, 325.

e. Orten, A. U., Some observations on the effects of low levels of dietary proteins. J. Nutrition, 1939, 17, (Suppl.), 14.

f. Fouts, P. J., Vitamin B complex studies in dogs, production of cirrhosis of liver. J. Nutrition, 1943, 25, 217.

g. Li, T., and Freeman, S., The frequency of "peptic ulcers" in protein-deficient dogs. Gastroenterology, 1946, 6, 140.

2. a. Ruggiero, W. F., Co Tui, and Bianco, A. A., The management of ambulatory peptic ulcer patients with protein hydrolysates. New York State J. Med., 1946, 46, 2398.

b. Co Tui, The ambulatory treatment of peptic ulcers with protein hydrolysates and dextri-maltose. Rev. Gastroenterol., 1947, 14, 108.

c. Kimble, S. T., Jr., A preliminary report on protein hydrolysate therapy for peptic ulcer. Gastroenterology, 1947, 8, 467.

d. Hodges, H. H., Protein hydrolysate therapy for peptic ulcer; report on 26 cases. Gastroenterology, $1947,8,476$.

e. Smith, M., and Friedenthal, B., Treatment of peptic ulcer with casein hydrolysate. J. M. Soc. New Jersey, 1948, 45, 17.

3. Kirsner, J. B., Sheffner, A. L., and Palmer, W. L., Studies on amino acid excretion in man. III. Amino acid levels in plasma and urine of normal men fed diets of varying protein content. J. Clin. Invest., 1949, 28, 716.

4. Hegsted, D. M., Tsongas, A. G., Abbott, D. B., and Stare, F. J., Protein requirements for adults. J. Lab. \& Clin. Med., 1946, 31, 261.

5. Sheffner, A. L., Kirsner, J. B., and Palmer, W. L., Studies on amino acid excretion in man. I. Amino acids in urine. II. Amino acids in feces. J. Biol. Chem., 1948, 175, 107; 176, 89. 
6. Hier, S. W., and Bergeim, O., The microbiological determination of certain free amino acids in human and dog plasma. J. Biol. Chem., 1946, 163, 129.

7. Campbell, W. R., and Hanna, M. I., The albumin, globulins, and fibrinogen of serum and plasma. J. Biol. Chem., 1937, 119, 15.

8. Sheffner, A. L., Kirsner, J. B., and Palmer, W. L., Studies on amino acid excretion in man. VI. Amino acids in plasma, urine and feces during ingestion of various protein supplements. (Submitted for publication).

9. Co Tui, Wright, A. M., Mulholland, J. H., Galvin, T., Barcham, I., and Gerst, G. R., The hyperalimentation treatment of peptic ulcer with amino acids (protein hydrolysate) and dextri-maltose. Gastroenterology, 1945, 5, 5.

10. Kenamore, B., Lonergan, W., and Shy, J. C., Protein hydrolysate therapy in peptic ulcer; a controlled study. Gastroenterology, 1948, 10, 177.

11. Sappington, T. S., and Bockus, H. L., Nitrogen balance studies in peptic ulcer disease. Ann. Int. Med., 1949, 31, 271.

12. a. Kirsner, J. B., and Palmer, W. L., Unpublished data.

b. Woldman, E. E., Fishman, D., Knowlton, R. S., Rausuck, A. A., and Stoner, W. C., Evaluation of protein hydrolysate therapy for peptic ulcer. J.A. M.A., 1948, 137, 1289.

13. Menon, A. N. K., Naganna, B., and Bai, K. J., Plasma proteins in peptic ulcer. Indian M. Gaz., 1948, 83, 403.

14. Marino, S., and Saladino, A., Cited by Godfried (15).

15. Godfried, E. G., Investigations on the polypeptidecontent of the serum. Biochem. J., 1939, 33, 955.

16. Becher, E., and Herrmann, E., Free and combined amino nitrogen in protein-free blood and tissues under normal and pathological conditions. I-IV. Deutsche Arch. klin. Med., 1931, 171, 529 and 547; 1932, 173, 1 and 23.

17. Christensen, H. N., Decker, D. G., Lynch, E. L., MacKenzie, T. M., and Powers, J. H., The conjugated, non-protein amino acids of plasma. V. A study of the clinical significance of peptidemia. J. Clin. Invest., 1947, 26, 853.

18. Seibert, F. B., and Nelson, J. W., Electrophoretic study of the blood protein response in tuberculosis. J. Biol. Chem., 1942, 143, 29.
19. a. Winzler, R. J., Devor, A. W., and Mehl, J. W., Isolation and characterization of proteose from human plasma. Cancer Research, 1946, 6, 496.

b. Winzler, R. J., Devor, A. W., Mehl, J. W., and Smyth, I. M., Studies on the mucoproteins of human plasma. I. Determination and isolation. J. Clin. Invest., 1948, 27, 609.

c. Winzler, R. J., and Smyth, I. M., Studies on the mucoproteins of human plasma. II. Plasma mucoprotein levels in cancer patients. Ibid., 1948, 27, 617.

d. Petermann, M. L., and Hogness, K. R., Electrophoretic studies on the plasma proteins of patients with neoplastic disease. II. An acid protein present in the plasma. Cancer, 1948, 1, 104.

20. Moore, D. H., and Lynn, J., Electrophoretic measurements on normal human plasma. J. Biol. Chem., 1941, 41, 819.

21. Svensson, H., Electrophoresis by the moving boundary method. A theoretical and experimental study. Arkiv. Kemi, Mineral., Geol., 1946, 22A, No. 10.

22. Chargaff, S., Ziff, M., and Moore, D. H., Studies on the chemistry of blood coagulation. XII. An electrophoretic study of the effect of anticoagulants on human plasma proteins with remarks on the separation of the heparin complement. J. Biol. Chem., 1941, 139, 383.

23. Berg, M. H., Balice, F. W., and Curtis, A. C., Electrophoretic investigations of vital fluids from patients with bullous diseases. Univ. Hospital Bull., Univ. of Michigan, 1949, 15, 62.

24. Shedlovsky, T., Personal communication.

25. a. Personal communication.

b. Cohn, E. J., Gurd, F. R. N., Surgenor, D. M., Barnes, B. A., Brown, R. K., Derouaux, G., Gillespie, J. M., Kahnt, F. W., Lever, W. F., Liu, C. H., Mittelman, D., Mouton, R. F., Schmid, K., and Uroma, E., A system for the separation of the components of human blood: quantitative procedures for the separation of the protein components of human plasma. J. Amer. Chem. Soc., 1950, 72, 465.

26. Longsworth, L. G., and MacInnes, D. A., An electrophoretic study of mixtures of ovalbumin and yeast nucleic acid. J. Gen. Physiol., 1941-42, 25, 507.

27. Meyer, K., and Chaffee, E., Hyaluronic acid in the pleural fluid associated with a malignant tumor involving the pleura and peritoneum. J. Biol. Chem., 1940, 133, 83. 